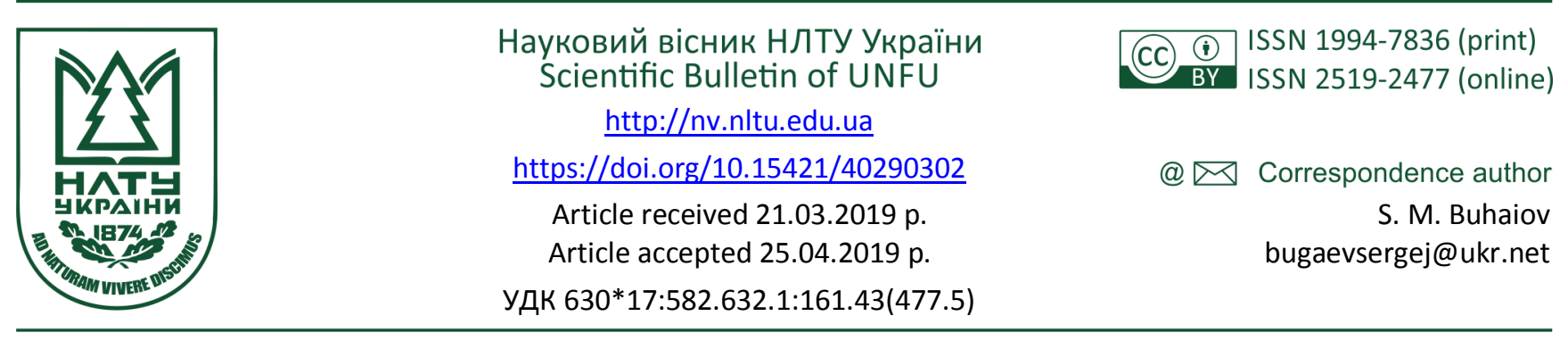

С. М. Бугайов ${ }^{1}$ В. П. Пастернак ${ }^{1,2}$, Ю. М. Біла ${ }^{1}$

${ }^{1}$ Харківський національний аграрний університет ім. В. В. Докучаєва, м. Харків, Украӥна

${ }^{2}$ Украӥнський НДІ лісового господарства і агромеліораиії ім. Г. М. Висоцького, м. Харків, Украӥна

\title{
ТАБЛИЦІ ХОДУ РОСТУ МОДАЛЬНИХ ВІЛЬХОВИХ ДЕРЕВОСТАНІВ ЛІВОБЕРЕЖНОГО ЛІСОСТЕПУ УКРАЇНИ
}

\begin{abstract}
Проаналізовано літературні джерела з проблематики дослідження ходу росту насаджень вільхи чорної вегетативного походження в Україні та за їі межами. Розглянуто передумови моделювання таксаційних показників вільхових деревостанів Лівобережного Лісостепу України. 3 метою виявлення закономірностей розподілу таксаційних показників вільхових деревостанів і визначення однорідності дослідних даних пробних площ і модельних дерев проведено їхній статистичний аналіз. Його результати підтверджують гіпотезу, що досліджувана база емпіричних даних достатньо повно описує насадження вільхи чорної і придатна для моделювання динаміки таксаційних показників. Побудовано моделі росту вільшанику регіону дослідження за висотою, діаметром, абсолютною повнотою та видовим числом. За результатами моделювання середньої висоти створено динамічну бонітетну шкалу, що відповідає одному типу росту. Керуючись отриманими моделями основних таксаційних показників, складено таблиці ходу росту модальних вільхових деревостанів вегетативного походження Лівобережного Лісостепу України для переважаючих класів бонітету. Порівняння отриманих нормативів з існуючими таблицями ходу росту вільхи чорної свідчить про наявність спільних закономірностей росту вільхових деревостанів. Водночас значуща різниця динаміки росту вільшанику окремих регіонів підтверджує необхідність складання регіональних таблиць ходу росту безпосередньо для Лівобережного Лісостепу України.
\end{abstract}

Ключові слова: вільха чорна; таксаційні показники; моделі росту; динамічна бонітетна шкала; вегетативне походження.

Вступ. Для вирішення різноманітних господарських завдань під час інтенсивного ведення лісового господарства необхідно вивчати ріст і продуктивність насаджень. Моделювання процесів росту і розвитку насаджень у лісових біогеоценозах розглянуто в багатьох дослідженнях (Munro, 1973; Antanaytis, 1976; Brooks, 1987). Для розроблення нормативів актуалізації таксаційних показників важливим елементом $є$ створення таблиць ходу росту та динамічної бонітетної шкали для модальних насаджень. Такі нормативи дають можливість об'єктивно оцінити лісосировинні ресурси найбільш представлених деревостанів, прогнозувати їхній ріст, а також контролювати ведення господарства в них (Zagreev, 1978).

У різні часи особливості росту деревостанів вільхи чорної досліджували багато лісівників (Davydov, 1960, 1979; Baginsky, 1985; Pasternak \& Storozhenko, 2010; Lakyda et al., 2017). Однак у чинній нормативній базі для таксації вільхових насаджень України використовують тільки таблиці ходу росту М. В. Давидова, опубліковані у 1960 p. (Davydov, 1960), незважаючи на те, що у 1979 р. цей автор розробив уточнені нормативи з ура- хуванням прискореного типу росту (Davydov, 1979).

У 2013 р. кафедрою лісової таксації та лісовпорядкування НУБіП України підготовлено "Лісотаксаційний довідник" (Dovidnyk, 2013), в якому зокрема міститься уніфікований і виправлений варіант нормативів М. В. Давидова 1979 р. Але, як і в попередній редакції таблиць ходу росту М. В. Давидова, навіть уточнені дані повною мірою не розкривають регіональні особливості росту вільшанику, що ускладнює ведення господарства в них. Враховуючи те, що для вільхових деревостанів Полісся (Lakida et al., 2017) та Степу (Pasternak \& Storozhenko, 2010) складено нормативи ходу росту, постала необхідність розроблення системи моделювання прогнозу росту порослевих вільшняків безпосередньо для умов Лівобережного Лісостепу.

Метою дослідження було вивчити закономірності ходу росту вільхових деревостанів регіону

Матеріали та методи дослідження. Для дослідження особливостей росту вільшанику вегетативного походження Лівобережного Лісостепу України опрацьовано дані 84 пробних площ, закладених автором або за його участі в різних частинах регіону дослідження (Bugayov, 2012). На 15-ти з них відібрано модельні дерева.

\section{Інформація про авторів:}

Бугайов Сергій Миколайович, канд. с.-г. наук, доцент, кафедра лісоуправління, лісоексплуатації та безпеки життєдіяльності. Email: bugaevsergej@ukr.net

Пастернак Володимир Петрович, д-р с.-г. наук, професор, пров. наук. співробітник, лабораторія моніторингу та класифікації лісів. Email: Pasternak65@ukr.net; https://orcid.org/0000-0003-1346-1968

Біла Юлія Миколаївна, канд. с.-г. наук, доцент, кафедра лісоуправління, лісоексплуатації та безпеки життєдіяльності. Email: belay_1980@ukr.net

Цитування за ДСту: Бугайов С. М., Пастернак В. П., Біла Ю. М. Таблиці ходу росту модальних вільхових деревостанів Лівобережного Лісостепу України. Науковий вісник НлтУ України. 2019, т. 29, № 3. С. 13-17.

Citation APA: Buhaiov, S. M., Pasternak, V. P., \& Bila, Yu. M. (2019). Growing tables of modal alder stands of vegetative origin of Ukrainian Left-Bank Forest-Steppe. Scientific Bulletin of UNFU, 29(3), 13-17. https://doi.org/10.15421/40290302

Науковий вісник НЛтУ України, 2019, т. 29, № $3 \quad$ Scientific Bulletin of UNFU, 2019, vol. 29, no 3 
Для виявлення закономірностей розподілу таксаційних показників вільхових деревостанів і визначення однорідності дослідних даних проведено їхній статистичний аналіз (табл. 1).

Табл. 1. Статистична характеристика таксаційних показників насаджень пробних площ

\begin{tabular}{|c|c|c|c|c|c|c|}
\hline Таксаційний & \multicolumn{7}{|c|}{ Статистика } \\
\cline { 2 - 7 } показник & $\mathrm{X}$ & $\delta$ & $E s$ & $A s$ & $\min$ & $\max$ \\
\hline$A$, років & 51,43 & 22,08 & $-0,12$ & 0,46 & 8,00 & 105,00 \\
\hline$D, \mathrm{~cm}$ & 24,48 & 8,46 & 0,30 & 0,39 & 5,50 & 47,30 \\
\hline$H, \mathrm{M}$ & 21,88 & 4,56 & 0,89 & $-0,78$ & 7,90 & 30,20 \\
\hline$G, \mathrm{~m}^{2} \cdot \mathrm{ra}^{-1}$ & 25,99 & 5,42 & 1,10 & 0,24 & 12,70 & 45,00 \\
\hline$P$ & 0,78 & 0,14 & 2,08 & $-0,94$ & 0,53 & 1,25 \\
\hline
\end{tabular}

Аналіз статистичних показників свідчить, що для віку $(A)$, середнього діаметра $(D)$, середньої висоти $(H)$, площі поперечного перерізу $(G)$ показники асиметрії та ексцесу в натуральних величинах не перевищують допустимі значення $(A s<1,0 ; E s<1,2)$. Для висоти й відносної повноти визначено лівосторонню асиметрію, тоді як для інших досліджуваних показників - правосторонню. Розподіл значень віку характеризується гостровершинною кривою, інших показників - туповершинною. Досліджувана база емпіричних даних достатньо повно описує насадження вільхи чорної і придатна для моделювання динаміки таксаційних показників.

Для визначення ступеня тісноти зв'язку між таксаційними показниками пробних площ вільхових деревостанів Лівобережного Лісостепу України побудовано кореляційну матрицю (табл. 2).

Табл. 2. Кореляційна матриця основних таксаційних показників ПІП

\begin{tabular}{|c|c|c|c|c|c|c|}
\hline Показник & $A$, років & $H, \mathrm{~m}$ & $D$, см & $N$, шт. & $P$ & $G, \mathrm{~m}^{2} \cdot \mathrm{ra}^{-1}$ \\
\hline$A$, років & 1,00 & 0,84 & 0,90 & $-0,66$ & $-0,43$ & 0,48 \\
\hline$H, \mathrm{M}$ & - & 1,00 & 0,85 & $-0,79$ & $-0,77$ & 0,67 \\
\hline$D, \mathrm{~cm}$ & - & - & 1,00 & $-0,71$ & $-0,41$ & 0,53 \\
\hline$N$, шт. & - & - & - & 1,00 & 0,47 & $-0,45$ \\
\hline$P$ & - & - & - & - & 1,00 & 0,35 \\
\hline$G, \mathrm{M}^{2} \cdot \mathrm{ra}^{-1}$ & - & - & - & - & - & 1,00 \\
\hline
\end{tabular}

Аналіз отриманих даних підтверджує наявність тісного зв'язку між собою таких показників, як: середній вік $(A)$, середній діаметр $(D)$, середня висота $(H)$. Відповідні коефіцієнти кореляції мають значення від 0,84 до 0,9 . Статистично значущими є зв'язки кількості дерев із середнім віком $(A)$, середнім діаметром $(D)$, оскільки обчислений коефіцієнт кореляції між цими показниками перевищує критичне його значення $(0,576)$.

Результати дослідження та їх обговорення. Під час дослідження ходу росту модальних деревостанів використовували статистичний та аналітичний методи у поєднанні. При цьому динаміку висот розраховували на основі даних аналітичного підходу, а всі інші параметри встановлювали за допомогою регресійних залежностей на статистичному матеріалі пробних площ і бази даних "Лісовий фонд".

Вивчення закономірностей ходу росту розпочато 3 моделювання динаміки середньої висоти, яка є основним таксаційним показником для оцінювання динаміки росту, оскільки вона тісно пов'язана 3 іншими таксаційними показниками деревостану (середнім діаметром, сумою площ перерізів, запасом) та має меншу мінливість (Tsurik, 2008). Для побудови бонітетної шкали за базовий вік було прийнято 50 років. У цьому віці, на думку багатьох дослідників (Munro, 1973; Zagreev, 1978; Antanaytis, 1976), стабілізується ріст у висоту дерев швидкорослих порід.
Після усереднення динаміки висот одержано характеристики росту у відносних величинах. За дослідними даними не виявлено істотної різниці в динаміці відносних висот за типами лісорослинних умов. У вільхових деревостанах регіону дослідження I клас бонітету є переважаючим, тому за основу для моделювання прийняті відносні висоти цього класу.

Для побудови моделей необхідно обрати рівняння, що відповідає всім вимогам до функцій росту, а саме: проходить через початок координат і монотонно зростає на всьому проміжку області визначення (Kiviste, 1988). На попередньому етапі дослідження ми використовували функцію Мітчерліха (Дракіна-Вуєвського) (Bugayov \& Pasternak, 2015), але після опрацювання всього зібраного матеріалу цю ростову функцію було змінено на функцію Берталанфі.

Після розрахунку параметрів функції для побудови нормативів було отримано таку математичну модель:

$H=1,320[1-\exp (-0,0183 A(1-\exp (-0,225 A)))]^{0,549} H_{50},(1)$ де: $H$ - висота, м; $H_{50}-$ висота у віці 50 років, м; $A-$ вік років.

Результати досліджень ходу росту за висотою дають змогу стверджувати, що для вільхових деревостанів Лісостепу $є$ характерним тип росту $T y$. Це підтверджується також динамікою середньоперіодичного приросту за висотою, який у 10 років становить 1,0 м, у 20 років - 0,8 м, у 30 років - 0,6 м. Таку закономірність встановив М. В. Давидов (Davydov, 1979), а також іiі підтвердили у роботах інші автори (Pasternak \& Storozhenko, 2010; Lakyda et al., 2017).

Перехід від відносних до абсолютних значень модельованих таксаційних показників здійснювали на основі базових значень висоти модифікованої шкали М. М. Орлова для порослевих деревостанів у віці 50 років, які становили для $\mathrm{I}_{\mathrm{a}}$, I і II класів бонітету 25,$3 ; 22,3$ і 19,3 м відповідно. Після проведених розрахунків 3 метою групування дослідного матеріалу було створено динамічну бонітетну шкалу. В їі основу покладено модель росту за висотою (1). Підставивши в модель замість базової висоти значення загальнобонітетної шкали М. М. Орлова, отримали динамічну бонітетну шкалу (табл. 3).

Табл. 3. Динамічна бонітетна шкала вільхових деревостанів Лівобережного Лісостепу України

\begin{tabular}{|c|c|c|c|}
\hline \multirow{2}{*}{$\begin{array}{c}A, \\
\text { років }\end{array}$} & \multicolumn{3}{|c|}{ Н за класами бонітету, м } \\
\cline { 2 - 4 } & $\mathrm{I}_{\mathrm{a}}$ & $\mathrm{I}$ & $\mathrm{II}$ \\
\hline 5 & $6,5-5,6$ & $5,7-5,1$ & $5,0-4,4$ \\
\hline 10 & $10,5-9,4$ & $9,3-8,2$ & $8,1-7,0$ \\
\hline 15 & $13,8-12,4$ & $12,3-10,8$ & $10,7-9,3$ \\
\hline 20 & $16,4-14,7$ & $14,6-12,8$ & $12,7-11,0$ \\
\hline 25 & $18,6-16,5$ & $16,4-14,4$ & $14,3-12,4$ \\
\hline 30 & $20,4-18,1$ & $18,0-15,8$ & $15,7-13,6$ \\
\hline 35 & $21,9-19,5$ & $19,4-17,0$ & $16,9-14,7$ \\
\hline 40 & $23,3-20,7$ & $20,6-18,0$ & $17,9-15,7$ \\
\hline 45 & $24,5-21,8$ & $21,7-19,0$ & $18,9-16,2$ \\
\hline 50 & $25,6-22,7$ & $22,6-19,8$ & $19,7-16,9$ \\
\hline 55 & $26,5-23,6$ & $23,5-20,5$ & $20,4-17,4$ \\
\hline 60 & $27,4-24,3$ & $24,2-21,2$ & $21,1-18,1$ \\
\hline 65 & $28,2-25,0$ & $24,9-21,8$ & $21,7-18,6$ \\
\hline 70 & $28,9-25,6$ & $25,5-22,3$ & $22,2-19,0$ \\
\hline
\end{tabular}

Порівняння отриманої бонітетної шкали зі шкалою М. М. Орлова (рис. 1) свідчить, що висоти вільхових насаджень у молодому віці в динамічній шкалі є більшими, ніж за шкалою М. М. Орлова, а після 40-річного віку - значно меншими. 


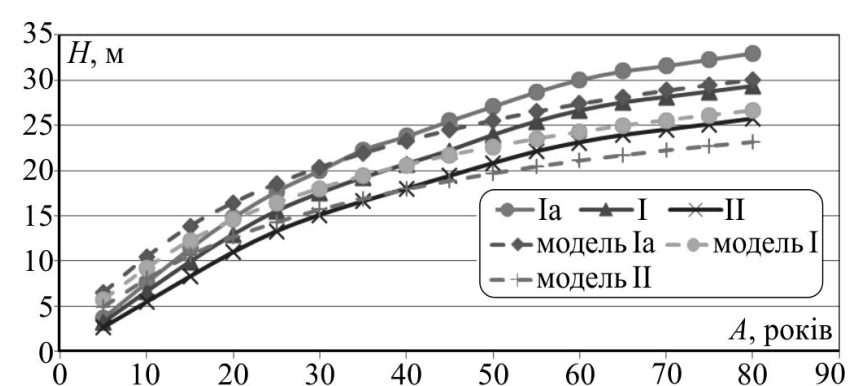

Рис. 1. Верхня межа класів бонітету за шкалою М. М. Орлова та динамічною шкалою

Отримана динамічна бонітетна шкала є прийнятною i можна їі надалі використовувати для групування експериментального матеріалу та аналізу ходу росту модальних насаджень вільхи чорної Лівобережного Лісостепу України. Динаміку середніх діаметрів $(D)$ модальних деревостанів встановлювали за співвідношенням $D / H$. Модель середнього діаметра для вільхових деревостанів Лівобережного Лісостепу України має такий вигляд:

$$
D / H=0,723 \cdot \exp (0,0063 \cdot A),
$$

де: $D$ - середній діаметр, см; $H$ - середня висота, м; $A-$ середній вік, років.

Оскільки аргументом функції постає середня висота, то за допомогою моделі (2) можна визначити середній діаметр насаджень будь-якого класу бонітету. Аналіз дисперсії залишків отриманої функції (рис. 2) свідчить про дотримання нормальності розподілу. Тобто вплив чинників, які не враховані в моделі, є незначним. Спільна їхня дія $є$ однаковою для всіх частин сукупності, а варіація середнього діаметра деревостану не залежить від їхнього рівня, що свідчить про адекватність розробленої моделі.

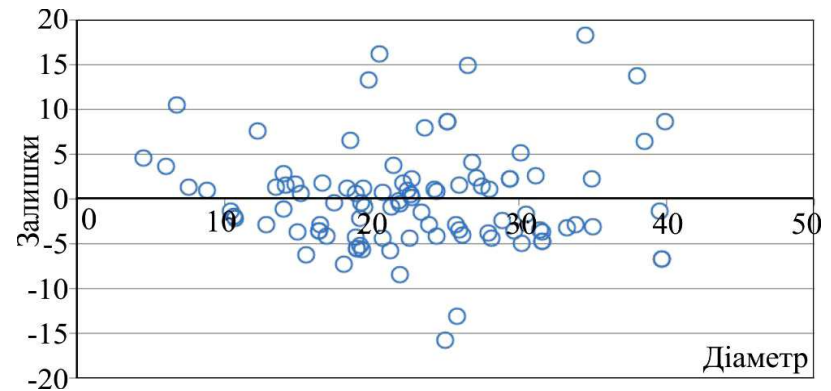

Рис. 2. Дисперсія залишків отриманої функції за діаметром

Однією з важливих складових таблиць ходу росту є інформація про запаси модальних деревостанів (Anuchin, 1982). Існують різні підходи до прогнозування цієі таксаційної ознаки, але найчастіше під час розроблення нормативів здійснюють моделювання запасів безпосередньо за даними пробних площ або обчисленням за класичною формулою лісової таксації з використанням видового числа $(F)$. Основним недоліком першого підходу $є$ істотна мінливість запасу, оскільки він зазнає впливу значної кількості слабоформалізовуваних чинників. Видове число є менш мінливим показником, тому для складання таблиць ходу росту було використано саме підхід з моделюванням цього показника.

Одним із найточніших способів визначення видового числа є його моделювання через видову висоту $(H F)$ (Tsurik, 2008), яка перебуває у тісному кореляційному зв'язку з віком $(A)$, висотою $(H)$ та діаметром $(D)$.

$$
H F=2,195 \cdot \operatorname{Ln}(A)+0,845,
$$

де: $H F$ - видова висота; $A-$ вік.
Статистичним підтвердженням адекватності моделі (3) є аналіз дисперсії залишків отриманої функції, який підтверджує на 5 \%-ому рівні дотримання нормальності розподілу (рис. 3).

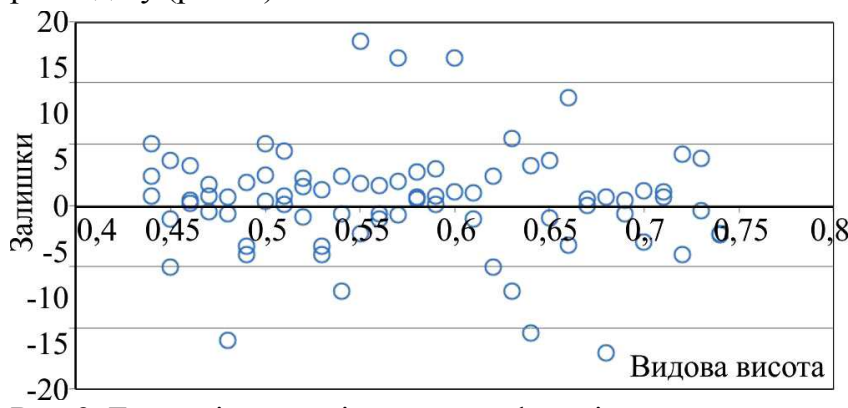

Рис. 3. Дисперсія залишків отриманої функції за числом видової висоти

Модель суми площ поперечних перерізів $(G)$ для чорновільхових деревостанів отримано як функцію середньої висоти $(H)$, оскільки значущого впливу класу бонітету на суму площ поперечних перерізів не встановлено. Під час побудови моделі були використано суми площ перерізу чистого і мішаного вільшанику, у складі яких не менше 8 одиниць вільхи чорної, при цьому площу перерізу моделювали за формулою

$$
G=33,145 \cdot\left(1-\exp (-0,125 \cdot(H-1,3))^{2,235},\right.
$$

де: $G$ - сума площ перерізу, м² $H$ - середня висота, м.

Для побудови моделі використано дані пробних площ, закладених у чистих і мішаних вільшаниках регіону дослідження, у складі яких не менше 8 одиниць вільхи чорної. У диференціації кількості дерев виявлено вікову динаміку, притаманну насадженням усіх класів бонітету. Загальні риси цієї закономірності підтверджують значний відпад дерев під час формування вільшанику. Інші параметри продуктивності вільхових деревостанів - запас $(M)$, середні $\left(\Delta_{M n m}\right)$ та поточні $\left(\Delta_{M n m}\right)$ зміни запасу - визначали за допомогою "класичних формул" лісової таксації (Anuchin, 1982).

На основі отриманих моделей складено таблиці ходу росту порослевих модальних вільхових деревостанів Лівобережного Лісостепу України для переважаючих класів бонітету (I ${ }^{\mathrm{a}}$, I та II). Фрагмент нормативів ходу росту модальних порослевих вільхових деревостанів для I класу бонітету, як найбільш представленого, наведено в табл. 4.

Дані ТХР групували на бонітетній основі, оскільки різниця певних таксаційних ознак є значущою для насаджень різних класів бонітету. До ТХР увійшли всі основні таксаційні характеристики вільхових деревостанів регіону дослідження: середній вік ( $A$, років), середня висота $(H, \mathrm{м})$, середній діаметр $(D$, см), кількість дерев $\left(N\right.$, шт. га $\left.{ }^{-1}\right)$, сума площ поперечних перерізів $(G$, $\left.\mathrm{M}^{2} \cdot \mathrm{ra}^{-1}\right)$, старе видове число $(F)$, запас $\left(M, \mathrm{M}^{3} \cdot \mathrm{ra}^{-1}\right)$, середня $\left(\Delta_{M c}, \mathrm{M}^{3} \cdot \mathrm{ra}^{-1}\right)$ та поточна $\left(\Delta_{M n m}, \mathrm{M}^{3} \cdot \mathrm{ra}^{-1}\right)$ зміни запасу.

Окрім статистичного підтвердження розроблених таблиць, було проведено порівняння основних лісівничо-таксаційних характеристик вільхових деревостанів регіону дослідження з аналогічними, що наведені у таблицях ходу росту порослевих деревостанів вільхи чорної I бонітету, які склав для умов Лісостепу та Полісся М. В. Давидов (Davydov, 1960) - чинні нормативи, та регіональними таблицями для умов Полісся, які розробили П. I. Лакида, В. І. Блищик, I. В. Блищик (Lakida et al., 2017) (табл. 5). 
Табл. 4. Хід росту модальних порослевих вільхових деревостанів Лівобережного Лісостепу України (бонітет I)

\begin{tabular}{|c|c|c|c|c|c|c|c|c|}
\hline \multirow{3}{*}{$A$, років } & \multicolumn{8}{|c|}{ Деревостан } \\
\hline & \multirow{2}{*}{$H$, м } & \multirow{2}{*}{$D, \mathrm{~cm}$} & \multirow{2}{*}{$N$, шт. га ${ }^{-1}$} & \multirow{2}{*}{$G, \mathrm{~m}^{2} \cdot \mathrm{ra}^{-1}$} & \multirow{2}{*}{$F$} & \multirow{2}{*}{$M, \mathrm{~m}^{3} \cdot \mathrm{ra}^{-1}$} & \multicolumn{2}{|c|}{$\Delta_{M}, \mathrm{M}^{3} \cdot \Gamma^{-1}$} \\
\hline & & & & & & & середня & поточна \\
\hline 5 & 6,3 & 4,7 & 3447 & 6,039773 & 0,691 & 26 & 5,3 & \\
\hline 10 & 10,5 & 8,1 & 2761 & 14,12488 & 0,563 & 83 & 8,3 & 11,4 \\
\hline 15 & 13,3 & 10,6 & 2151 & 18,84413 & 0,511 & 128 & 8,5 & 8,9 \\
\hline 20 & 15,4 & 12,6 & 1741 & 21,73121 & 0,483 & 161 & 8,1 & 6,7 \\
\hline 25 & 17,0 & 14,4 & 1451 & 23,66654 & 0,464 & 187 & 7,5 & 5,2 \\
\hline 30 & 18,4 & 16,1 & 1234 & 25,05195 & 0,451 & 208 & 6,9 & 4,2 \\
\hline 35 & 19,6 & 17,7 & 1065 & 26,08798 & 0,441 & 226 & 6,4 & 3,5 \\
\hline 40 & 20,6 & 19,2 & 931 & 26,88663 & 0,434 & 240 & 6,0 & 3,0 \\
\hline 45 & 21,5 & 20,7 & 822 & 27,51644 & 0,428 & 253 & 5,6 & 2,5 \\
\hline 50 & 22,3 & 22,1 & 731 & 28,02214 & 0,423 & 264 & 5,3 & 2,2 \\
\hline 55 & 23,0 & 23,5 & 654 & 28,43428 & 0,419 & 274 & 5,0 & 2,0 \\
\hline 60 & 23,6 & 24,9 & 589 & 28,77444 & 0,416 & 283 & 4,7 & 1,8 \\
\hline 65 & 24,2 & 26,3 & 533 & 29,05826 & 0,414 & 291 & 4,5 & 1,6 \\
\hline 70 & 24,7 & 27,7 & 485 & 29,2973 & 0,412 & 298 & 4,3 & 1,4 \\
\hline 75 & 25,1 & 29,2 & 442 & 29,50031 & 0,411 & 304 & 4,1 & 1,3 \\
\hline 80 & 25,5 & 30,6 & 404 & 29,67397 & 0,410 & 310 & 3,9 & 1,2 \\
\hline
\end{tabular}

Аналіз результатів проведених досліджень вільхових насаджень Лівобережного Лісостепу України (табл. 5) свідчить про те, що висоти до 40-річного віку є вищими, ніж за таблицями ходу росту повних порослевих чорновільхових деревостанів, складених для умов Лісостепу та Полісся, та за таблицями модальних деревостанів Українського Полісся у віці 20 років - на 8,4 та 9,1 \% відповідно, у 30 років - на 1,6 та 3,8 \%. Починаючи 340 років, за нашими даними, динаміка висот менша, ніж за нормативами інших авторів. Різниця за висотою, за даними М. В. Давидова, становить від 3,1\% (50 та 80 років) до $3,4 \%$ (у 60 років), за даними П. І. Лакиди - від $0,9 \%$ у віці 50 років до $3,1 \%$ у 80 років. Різниця за діаметром, за даними М.В.Давидова, більш значуща - від 9,2 \% у 80 років до $17,6 \%$ у 50 років. Натомість різниця за діаметром, відповідно до значень П. І. Лакиди, хоч і становить у віці 30 років 17,4 \%, проте 3 віком зменшується і у віці 80 років становить $1,3 \%$. Результати порівняння свідчать про значущу різницю динаміки росту вільшанику для різних регіонів та України загалом, що підтверджує необхідність складання регіональних таблиць ходу росту безпосередньо для Лівобережного Лісостепу України.

Табл. 5. Порівняльна характеристика ходу росту порослевих вільхових деревостанів за даними різних авторів \begin{tabular}{|l|c|c|c|}
\hline Вік, & Дані автора & За М. В. Давидовим & За П. І. Лакидою \\
\hline
\end{tabular}

\begin{tabular}{|c|c|c|c|c|c|c|}
\multirow{2}{*}{ років } & $H, \mathrm{~m}$ & $D, \mathrm{~cm}$ & $H, \mathrm{~m}$ & $D, \mathrm{~cm}$ & $H, \mathrm{M}$ & $D, \mathrm{~cm}$ \\
\hline 20 & 15,4 & 12,6 & 14,1 & 12,6 & 14,0 & 14,6 \\
\hline 30 & 18,4 & 16,1 & 18,1 & 17,9 & 17,7 & 18,9 \\
\hline 40 & 20,6 & 19,2 & 20,9 & 22,3 & 20,4 & 22,3 \\
\hline 50 & 22,3 & 22,1 & 23,0 & 26,0 & 22,5 & 25,1 \\
\hline 60 & 23,6 & 24,9 & 24,4 & 29,0 & 24,1 & 27,4 \\
\hline 70 & 24,7 & 27,7 & 25,5 & 31,4 & 25,3 & 29,3 \\
\hline 80 & 25,5 & 30,6 & 26,3 & 33,4 & 26,3 & 31,0 \\
\hline
\end{tabular}

Під час порівняння таксаційних показників за таблицями ходу росту повних і модальних деревостанів варто враховувати методичні особливості їхнього складання. Під час моделювання динаміки модальних деревостанів таксаційні показники визначали для деревостану загалом, а частину, що видаляється, не виділяли. Водночас для таблиць ходу росту повних деревостанів таксаційні показники розраховували окремо для основної частини та частини, що видаляється. Розподіл деревостану на частини, що залишається та видаляється, під час моделювання динаміки таксаційних показників має значний вплив на їхні значення, особливо на середній діаметр, суму площ поперечних перерізів і запас. Зна- чення діаметра при цьому завищуються, а суми площ поперечних перерізів і запасів на 1 га занижуються.

Висновки. Результати дослідження росту порослевих деревостанів вільхи чорної підтверджують наявність двох етапів росту для вільшанику.

За результатами моделювання середньої висоти створено динамічну бонітетну шкалу, в основу якої покладено один тип росту. Отриману шкалу можна використовувати для групування експериментального матеріалу та прогнозування ходу росту модальних насаджень вільхи чорної Лівобережного Лісостепу України.

На основі отриманих моделей росту складено таблиці ходу росту порослевих модальних вільхових деревостанів Лівобережного Лісостепу України для переважаючих класів бонітету, до яких увійшли основні таксаційні характеристики. Ці нормативи можна використати для ведення господарства у вільшанику Харківської, Сумської та Полтавської областей.

Отримані результати підтверджують відмінність росту вільхових деревостанів регіону дослідження від інших лісогосподарських зон та України загалом. При цьому вони узгоджуються із загальними закономірностями росту вільхових деревостанів і результатами досліджень інших авторів.

\section{Перелік використаних джерел}

Antanaytis, V. V. (1976). Regularities of Forest Taxation. Kaunas: Lit. Agr. Acad., 128 p. [In Russian].

Anuchin, N. P. (1982). Forest taxation. (5th ed.). Moscow: Forest Industry, 550 p. [In Russian].

Baginsky, V. F. (1985). Regularities of the structure and growth of the stands in the zone of intensive anthropogenic impact (on the example of the Byelorussian SSR). Abstract of Candidate Dissertation for Agricultural Sciences (06.03.02 - Forest Management and Forest Taxation). Kyiv, 35 p. [In Russian].

Brooks, D. J. (1987). Modelling forest dynamics. The global forest sector, an analytical perspective. NASA John Wiley and Sons. Chichester, 91-108.

Bugayov, S. M. (2012). Alder forest stands of the Slobozhansky district of the fresh temperate climate area. Scientific bulletin of NULES of Ukraine, 171(3), 107-113. [In Ukrainian].

Bugayov, S. M., \& Pasternak, V. P. (2015). Growth models of coppice alder stands of the Left-bank forest-steppe of Ukraine. Scientific Bulletin of UNFU, 25(2), 36-42. [In Ukrainian].

Davydov, M. V. (1960). Black alder of the European part of the USSR. Kyiv: UASGN, 113 p. [In Ukrainian].

Davydov, M. V. (1978). Alder. Moscow: Forest Industry, 78 p. [In Russian]. 
Kashpor, S. M., \& Strochinsky, A. A. (Eds). (2013). Forest Taxation Handbook. Kyiv: Publishing House "Vinnichenko", 496 p. [In Ukrainian].

Kiviste, A. K. (1988). Functions of forest growth. Tartu: Estonian Agr. Acad., 108 p. [In Russian].

Lakyda, P. I., Blishchik, V. I., \& Blishchik, I. V. (2017). Primary production of the European alder forests of Ukrainian Polissya. KorsunShevchenkivskyi: FOP Gavryshenko V. M., 245 p. [In Ukrainian].

Munro, D. D. (1973). Forest growth models - a prognosis. Growth models for tree and stand simulation, (pp. 7-19). Stockholm.
Oborska, A. E. (2010). The modeling of middle height dynamic of modal alder forest stands in Western Polissya of Ukraine]. Scientific Bulletin of UNFU, 20(1), 63-67. [In Ukrainian].

Pasternak, V. P., \& Storozhenko, V. I. (2010). Peculiarities of the growth of alder stands in the middle course of the Severski Donets. Scientific herald of the National University of Bioresources and $\mathrm{Na}$ ture Management of Ukraine, 147, 246-251. [In Ukrainian].

Tsurik, Ye. I. (2008). Taxation of forest stands dynamic. Lviv: UNFU, 345 p. [In Ukrainian].

Zagreev, V. V. (1978). Geographical regularities of growth and productivity of forest stands. Moscow: Forest industry, 239 p. [In Russian].

S. M. Buhaiov' ${ }^{1}$ V. P. Pasternak1,2, Yu. M. Bila ${ }^{1}$

${ }^{1}$ Kharkiv National Agrarian University named after V. V. Dokuchaev, Kharkiv, Ukraine ${ }^{2}$ Ukrainian Research Institute of Forestry and Forest Melioration named after H.M. Vysotskiy, Kharkiv, Ukraine

GROWING TABLES OF MODAL ALDER STANDS OF VEGETATIVE ORIGIN OF UKRAINIAN LEFT-BANK FOREST-STEPPE

Intensive forest management requires studying the growth and productivity of forest stands for solving various management tasks. The peculiarities of the growth of black alder stands were studied by many foresters. However, for modeling estimated features of alder stands the growth tables by M. Davydov for Forest-steppe and Polissya are most widely used. Consequently, it is necessary to develop a regional system for modeling the growth of coppice alder stands for the conditions of the Left Bank Forest-steppe. The data on 84 sample plots, located in different parts of the study area were processed in our study, on 15 of them model trees were selected. After processing the data of sample plots and model trees, in order to identify the patterns of distribution of estimated features of alder stands and to determine the homogeneity of experimental data, their statistical analysis was carried out, which confirms the hypothesis that the studied base of empirical data sufficiently describes the black alder stands and is suitable for simulation of taxation dynamics indicators. During the research, statistical and analytical methods in combination were used. The heights dynamics were calculated based on the data of the analytical approach, and all other parameters were defined using regression dependences on the statistical material of the sample plots and the Forest Fund database. The model of the growth of alder stands in the region of study was constructed in terms of height, diameter, density of stocking, and form factor. Based on the results of the average height modeling, a dynamic productivity scale corresponding to one type of growth has been created. Based on the received models of the basic estimated features, the table of the growth of the modal coppice alder stands of the Left Bank Foreststeppe of Ukraine for the prevailing productivity classes is compiled. The developed norms, although consistent with the general regularities of the growth of alder stands, however, better describe the growth dynamics in the regional aspect. This confirms the necessity of creation regional tables for the black alder stands of the Left-Bank Forest-steppe of Ukraine.

Keywords: black alder; forest-taxation indices; growth models; dynamic productivity scale; coppice origin. 